Western University

Scholarship@Western

2021

The New Bankruptcy 'Detective Agency'? The Origins of the Superintendent of Bankruptcy in Great Depression Canada

Thomas G. W. Telfer

Follow this and additional works at: https://ir.lib.uwo.ca/lawpub

Part of the Law Commons 
This is a pre-copy edited, post-peer reviewed version of the contribution accepted for publication in Canadian Business Law Journal. Reproduced by permission of Canada Business Law Journal Inc. and Thomson Reuters Canada Limited.

(2021) 64:1 Canadian Business Law Journal 22-45

\title{
THE NEW BANKRUPTCY "DETECTIVE AGENCY"'? THE ORIGINS OF THE SUPERINTENDENT OF BANKRUPTCY IN GREAT DEPRESSION CANADA
}

\author{
Thomas G.W. Telfer*
}

In the depths of the Great Depression, R.B. Bennett's Conservative government appointed W.J. Reilley as Canada's first Superintendent of Bankruptcy. Reilley's experience made him eminently qualified. He had trained as a lawyer and had been the Registrar of the Bankruptcy Court of Ontario at Osgoode Hall for many years. The creation of the federal Superintendent's office in 1932 is one of the major milestones in the legislative history of Canadian bankruptcy law. In the bankruptcy law literature, there is a broad recognition that the 1932 reforms were vital. These accounts are incomplete. This article seeks to provide a fuller understanding of these reforms by examining sources of opposition to the establishment of the Superintendent's office. Not all accepted the new regulatory approach and the prospects of a bankruptcy bureaucracy during the Depression. Within months of Reilley taking office, critics called into question his qualifications and demanded his resignation. Little is known about the 1932 reforms as the creation of the Superintendent's office has largely been overshadowed in the insolvency field by the enactment of corporate reorganization legislation in 1933 and farm credit legislation in 1934.

\section{Bankruptcy}

If you have lost the human touch, What you have left is nothing much.

Best strip yourself until you see, You've lost your own humanity.

And nothing found: You've nought to give, And really have no cause to live.

\footnotetext{
1. “Canada’s Bankruptcy Superintendent” (1933) 7 J. Nat'l Ass'n Ref. Bankr. 109.

* Professor, Faculty of Law, Western University. An earlier version of this paper was presented at The Canadian Confederation: Past, Present, and Future, Université de Montréal and workshops at the Osgoode Society; University of Helsinki; Queensland University of Technology and Melbourne University. I would thank participants from those workshops and James Struthers, Peter Neary, Jassmine Girgis, Anna Lund and Virginia Torrie for their comments. Oliver Hutchison, Stephanie Zuk and Chirine Ali provided research assistance.
} 
The Globe, (October 8, 1934), 6.

\section{INTRODUCTION}

In the depths of the Great Depression, Prime Minister Bennett's Conservative government appointed William J. Reilley as Canada's first Superintendent of Bankruptcy. The creation of the Superintendent's office in $1932^{2}$ is one of the major milestones in the legislative history of Canadian bankruptcy law. The amendments to the federal Bankruptcy Act gave the new Superintendent broad investigatory and supervisory powers over the bankruptcy regime. Reilley's experience made him eminently qualified for the position. ${ }^{3}$ He had trained as a lawyer and had been the Registrar of the Bankruptcy Court of Ontario at Osgoode Hall for eight years. ${ }^{4}$ In the bankruptcy law literature, there is a broad recognition of the importance of the 1932 reforms. The Superintendent of Bankruptcy continues to play an essential role in the supervision of the bankruptcy regime.

This article provides an account of the origins of the Superintendent's office and addresses two gaps in the existing literature. ${ }^{5}$ First, there has been no assessment of the amendments in the context of the Great Depression. The economic crisis might have hastened the reforms, but the 1932 amendments were not a reaction to the Great Depression. The Bankruptcy Act amendments did nothing to assist individuals coping with the financial fallout from the Great Depression, as the reforms only had an administrative focus. Simply, debt relief was not the focus of the 1932 amendments. The new regulatory regime responded to concerns about dishonest and corrupt trustees that had been raised in the 1920s, before the onset of the Great Depression. The roots of the legislation therefore can be found in the 1920s rather than in the Great Depression itself. Second, the article seeks to provide a more complete understanding of the 1932 reforms by examining sources of opposition to the establishment of the Superintendent's office. Not all accepted the new regulatory approach and the prospect of a bankruptcy bureaucracy. Within months of Reilley taking

\footnotetext{
2. An Act to amend the Bankruptcy Act, S.C. 1932, c. 39. The amendments came into force on December 1, 1932. See Bankruptcy Act, to amend (1932, c. 39), (1932) C. Gaz, 724. Minute of Meeting of Privy Council, P.C. 2047, (September 14, 1932), Department of Justice Papers, R.G. 13-A, Box 2217, File No. 1932-1934, Library and Archives Canada (L.A.C).

3. See Lewis Duncan, "The Bankruptcy Act Amendment Act of 1932: Part II" (1932), 2 Fortnightly L.J. 101, at p. 103.

4. Kenneth R. Wilson, "Bankruptcy Head has $\$ 50,000,000$ Job: W.J. Reilley Thinks New Federal Statute is Good Weapon to Stem Bankruptcy Abuses in Canada," The Financial Post, October 1, 1932, pp. 1, 8.

5. There are some limited accounts of the developments leading up to the 1932 amendments. The best account is John Honsberger, "Bankruptcy Administration in the United States and Canada" (1975), 63 Cal. L. Rev. 1515, at p. 1534. See also Henri Massü-Monat, "Méchanismes Administratifs Surintendant et Séquestre Officiel" in Albert Bohémier, Faillite et Insolvabilité, Tome 1 (Montreal: Éditions Thémis, 1992) at p. 484; Canada, Report of the Study Committee on Bankruptcy and Insolvency Legislation (Ottawa: Queen's Printer, 1970) at p. 18; Louise Lalonde, "Fairness and Due Process, Update on the Disciplinary Powers of the OSB Over Trustees" in Janis Sarra and Barbara Romaine, eds., Annual Review of Insolvency Law 2006 (Toronto: Carswell, 2007) 7; Sam Lévy \& Associés Inc. v. Mayrand, 2005 F.C. 702, at paras 63-65.
} 
office, critics called into question his qualifications and demanded his resignation. Part II of the article places the reforms in the context of the Great Depression, Part III examines the origins of the office of the Superintendent and Part IV focuses on the arguments of those who opposed the new Superintendent. Part V concludes. This is the first in-depth historical account of the Superintendent of Bankruptcy.

\section{THE BANKRUPTCY DISCHARGE AND THE GREAT DEPRESSION}

When Parliament debated the amendments to the Bankruptcy Act in April and May of 1932, Members of Parliament ("MPs") had an opportunity to re-assess the role of the discharge in the credit economy of the Great Depression. The bankruptcy law debates coincided with a devastating unemployment crisis. By the spring of 1932, "[Prime Minister] Bennett, with the rest of the country, seemed to have hit rock bottom." ${ }^{6}$ One might assume that the 1932 amendments to the Bankruptcy Act were a response to the economic crisis. Parliament might have made substantive changes to the bankruptcy discharge to provide debtors with greater relief. Parliament did not. Alternatively, Parliament could have emulated Western provincial debt adjustment legislation. In the 1920s, Saskatchewan and Alberta had aggressively forged ahead in enacting debtor legislation aimed at sheltering debtors from the actions of creditors. ${ }^{7}$ Manitoba introduced similar legislation in $1931 .^{8}$ Provincial debt adjustment legislation enacted broad stays against creditors and enabled administrative boards to prevent creditors from "oppressively" using the law "to assert his rights" against debtors. ${ }^{9}$ Provinces that took steps to enact debt adjustment legislation must have considered the Bankruptcy Act "insufficient or poorly suited to their regional needs." 10 When

\footnotetext{
6. James Struthers, No Fault of Their Own: Unemployment and the Canadian Welfare State 1914-1941 (Toronto, University of Toronto Press, 1983) at p. 69.

7. See Thomas G.W. Telfer, "Rediscovering the Bankruptcy and Insolvency Power: Political and Constitutional Challenges to the Canadian Bankruptcy Act, 1919-1929" (2017), 80 Sask. L. Rev. 37. Saskatchewan: The Drought Relief Act, S.A. 1922, c. 43; The Debt Adjustment Act, S.A. 1923, c. 43; The Debt Adjustment Act, R.S.S. 1928-29, c. 53. As of 1932, The Debt Adjustment Act, S.S. 1932, c. 51 was in force in Saskatchewan. Alberta: The Debt Adjustment Act, S.A. 1931, c. 57; The Debt Adjustment Act, S.A. 1933, c. 13. The Alberta legislation was eventually ruled ultra vires by the Privy Council in 1943: Reference Re: Debt Adjustment Act, 1937 (Alberta), [1943] 2 D.L.R. 1 (P.C.). As early as 1934, the Department of Justice considered provincial debt adjustment legislation to be ultra vires. "Memorandum for Deputy Minister of Justice, (January 22, 1934), Department of Justice Papers, R.G. 13 vol. 391, File 1577, L.A.C.

8. See The Debt Adjustment Act, S.M. 1931, c. 7 and The Debt Adjustment Act, S.M. 1932, c. 8. For commentary on the scope of the Manitoba legislation see F.R., "Recent Manitoba Legislation" (1931), 1 Fortnightly L.J. 25, at p. 29. For an overview of the operation of debt relief legislation see Roderick Wood, "Enforcement Remedies of Creditors" (1996), 34 Alta L. Rev. 783, at p. 786; S. David Cohen, "Law, Order and Democracy: An Analysis of the Judiciary in a Progressive State-the Saskatchewan Experience" (1992), 56 Sask. L. Rev. 23, at p. 31.

9. Mutual Life Assurance v. Levitt, [1939] 2 D.L.R. 324 (Alta S.C. (A.D.)), at p. 329. In 1934, there was a belief that Bennett might amend the Bankruptcy Act to somehow suspend provincial moratorium laws. This never happened but later that year Bennett would enact the F.C.A.A. See "Bennett May Amend the Bankruptcy Act to Nullify Moratoria," The Financial Post, March 24, 1934, p. 1.

10. Albert Bohémier, "Bankruptcy and Insolvency" (January 7, 2015), at Part I-A (study delivered to Civil Law Section of the Department of Justice) online <https://www.justice.gc.ca/eng/rp-pr/csj-sjc/harmonization/bohemier/bankrfailli.html $>$.
} 
Parliament amended the Bankruptcy Act in 1932, federal MPs chose not to follow provincial reforms. ${ }^{11}$

A review of Hansard and the proceedings of the Special Committee appointed to review the 1932 bankruptcy Bill reveals that there is no mention of using a revised Bankruptcy Act to respond to the Great Depression. The resolution that accompanied the Bill's introduction to the House focused solely on administrative reforms: ${ }^{12}$

Resolved, that it is expedient to bring in a measure to amend the Bankruptcy Act, and to provide for the administration of the act by the Minister of Finance, and for the appointment of a superintendent of bankruptcy...and for the licensing of trustees and payment of fees therefore.

One Member of Parliament summed up the effects of the 1932 Bill: "[T]he provisions of this Bill undoubtedly give a great deal more protection to the creditors than they have had in the past." 13 Most of the Parliamentary debate on the Bill focused on administrative matters such as the desirability of appointing a new Superintendent of Bankruptcy and of the licencing of trustees in bankruptcy. In 1932, it appears as if Parliament was content to allow provinces to deal with the protection of debtors. $^{14}$

During the Great Depression, Parliament was certainly aware of the plight of insolvent debtors. It eventually passed specific federal legislation to protect insolvent companies in $1933^{15}$ and insolvent farmers in 1934. ${ }^{16}$ The Farmers' Creditors Arrangement Act ("F.C.A.A.") ${ }^{17}$ allowed families to remain on the farm rather than face foreclosure. A board had the authority to "write down debt to manageable proportions and draw up repayment terms which would give the farmer a new start." The F.C.A.A. "compromised the Conservative government's adamance about the sanctity of private contracts." 18 Perhaps the farming community was too important to be ignored. ${ }^{19}$ But there was to be no similar relief for non-farming debtors. In 1933, Bennett was asked in the House of Commons whether Parliament might act to assist debtors who had defaulted on home mortgages. One MP expressed concern about homeowners who "find themselves ousted" by

\footnotetext{
11. Parliament responded to debt adjustment legislation by passing the Farmers' Creditors Arrangement Act, S.C. 1934, c. 53. The F.C.A.A. sought to protect farmers from creditors. Ordinary non-farmer debtors received no similar protection from the 1932 amendments to the Bankruptcy Act.

12. Canada, House of Commons, Official Report of Debates (Hansard), II (April 5, 1932), at p. 1703 (Hon. Hugh Guthrie).

13. Canada, Senate, Official Report of Debates (Hansard), I (May 24, 1932), at p. 462 (Hon. Mr. Little).

14. See P.B. Waite, In Search of R.B. Bennett (Montreal and Kingston: McGill-Queen's University Press, 2012) at p. 128.

15. Companies' Creditors Arrangement Act, S.C. 1933, c. 36.

16. Farmers' Creditors Arrangement Act, S.C. 1934, c. 53.

17. Virginia Torrie, "Farm Debt Compromises during the Great Depression" (2018), 41 Man. L.J. 377; Virginia Torrie, "Federalism and Farm Debt during the Great Depression: Political Impetuses for the Farmers' Creditors Arrangement Act, 1934” (2019) 82:2 Sask. L. Rev. 203.

18. John Herd Thompson and Allen Seager, Canada 1922-1939: Decades of Discord (Toronto, University of Toronto Press, 1985) at p. 257.

19. On the political reasons for the enactment of the F.C.A.A. see Virginia Torrie, "Federalism and Farm Debt", supra, footnote 17.
} 
creditors. Bennett replied that this "is a matter solely within the jurisdiction of the province....[W]e cannot exercise any jurisdiction." 20

\section{THE SUPERINTENDENT OF BANKRUPTCY AND LICENCING TRUSTEES}

\section{Trustee Practices in the 1920s and Demands for Reform}

The new regulatory approach of 1932 largely responded to complaints about fraudulent trustees that had arisen during the 1920s and were not specific to the economic crisis. Parliament looked back to the 1920s as an inspiration for reform. The Bankruptcy Act and the 1923 amending legislation gave rise to fraudulent trustee practices during the 1920s. Investigations into these trustee practices began before the stock market crash of 1929. In 1929, Lewis Duncan responded to the trustee crisis by recommending that "there was a need in Canada for an adequately staffed bankruptcy department with offices at strategic centres." 21

The best summary of abusive trustee practices in Canada is found in Robert H. Thayer's thirty-page Report on Bankruptcy Administration in Canada published in 1930. ${ }^{22}$ Although released on March 22, 1930, it is clear that Thayer began his investigation before the crash. Thayer reviewed all trustee reports of liquidated estates for the period November 1, 1928 - September 7, $1929 .^{23}$ Thayer identified fraudulent trustees as one of the main abuses arising from the operation of the Bankruptcy Act. He found that "fraudulent trustee organizations who, with the assistance of dishonest debtors, are able through the machinery of the Act to gain control over estates... as Trustees." 24 Thayer discovered evidence of fictitious creditor claims being filed to "control the election of the Trustee." ${ }^{25}$ In the West, Thayer heard complaints of trustees favouring debtors by "not searching too severely for fraud, in order to gain the reputation of being favorable to debtors." 26 In Québec, Thayer noted that business practices were different in that there "is a large foreign element in business chiefly from Central Europe." 27 Thus, in Québec "dishonest bankruptcies are frequent and fraudulent trustee organizations and individuals exist in large numbers." Thayer reported that "Incompetent and untrustworthy individuals who are not in the liquidation business are quite often asked for and appointed Custodian and gain election as Trustee, and often the debtor's own accountant is able to obtain these positions. ${ }^{28}$ Thayer noted a significant demand in the East "for a system that will protect creditors from dishonest Trustees and permit only competent and trustworthy organizations to conduct a liquidation business." 29

20. Canada, House of Commons, Official Report of Debates (Hansard), 4 (June 4, 1934), at p. 3645 (Venoit) (Bennett).

21. Report of the Study Committee on Bankruptcy, supra, footnote 5, at p. 18.

22. Robert H. Thayer, Report on Bankruptcy Administration in Canada [Thayer Report] in William J. Donovan, In the Matter of an Inquiry into the Administration of Bankrupts' Estates Conducted before Hon. Thomas D. Thatcher, Judge of the United States District Court for the Southern District of New York (New York: Court Press, 1930) [Donovan Report].

23. Ibid., at p. 237.

24. Ibid., at p. 260.

25. Ibid., at p. 261.

26. Ibid., at pp. 261-2.

27. Ibid., at p. 262. Perhaps this was a veiled reference to the Jewish population in Montreal. This view is consistent with the anti-Semitism expressed in Québec as discussed later in the article.

28. Ibid.

29. Ibid. 
The Canadian Bar Association ("CBA") also studied abusive trustee practices from the 1920s and issued a Report of the Special Committee on Bankruptcy on August 28, 1931. ${ }^{30}$ The origins of this report also pre-date the Great Depression. In 1929, the Montreal Bar Association investigated allegations of trustee malpractice and found that there "was a deplorable state of affairs." 31 This report led the CBA to authorize its own study in August 1930. The CBA listed the principal criticisms of the bankruptcy regime as (i) the trustee is dishonest (ii) the trustee is inefficient and (iii) the trustee is administering the estate for the benefit of debtors or specific creditors. ${ }^{32}$ The economic crisis did not lead the CBA to recommend any changes to the debtor relief regime. The CBA Committee concluded that it was "not advisable to effect any changes to the substance of the Bankruptcy Act itself." ${ }_{33}$ The Committee only recommended that the "administration of the Act must be changed." 34 Parliament ultimately adopted the two major CBA recommendations: ${ }^{35}$ (i) the creation of a Superintendent of Bankruptcy and (ii) the establishment of a licencing regime for trustees. In introducing the Bankruptcy Bill, the Minister of Justice, Hugh Guthrie, announced to the House that "it would be in the interests of the whole community" for Parliament to adopt the CBA's proposals as amendments to the Bankruptcy Act. ${ }^{36}$ R.B. Bennett had served as President of the CBA from 1929-30, ${ }^{37}$ just before the CBA issued its Report. It is not surprising that when he became Prime Minister, the CBA Report became the very basis for the bankruptcy Bill.

\section{The Powers of the Superintendent and Licencing of Trustees}

Following the CBA's recommendation, Parliament created the office of the Superintendent of Bankruptcy. ${ }^{38}$ An internal memorandum prepared for the Minister of Justice outlined the shift away from creditor control: "It appears to be the case that the administration of bankrupt estates must be supervised by the government." 39 Operating out of a new department of the Ministry of Finance, William J. Reilley, as Superintendent, had responsibility for supervising "the administration of all bankrupt or insolvent estates." ${ }^{40}$ With this responsibility came broad powers

\footnotetext{
30. Canadian Bar Association, Report of the Special Committee on Bankruptcy (1931) [C.B.A. Report].

31. Ibid., at p. 1. The Canadian Bar Association committee was comprised of the President of the C.B.A., Louis St. Laurent and leading bankruptcy experts including: H.P. Grundy, Lewis Duncan and Jacques Panneton. "Amendment urged to Bankruptcy Act by Public Bodies" (undated press clipping), Department of Justice Papers, R.G. 13-A, Box 2217, File No. 1932-1934, L.A.C.

32. Memorandum for Deputy Minister of Justice, (February 4, 1932), Department of Justice Papers, R.G. 13-A, Box 2217, File No. 1932-1934, L.A.C, at p. 1.

33. C.B.A., Report of Special Committee, supra, footnote 30, at p. 1.

34. Ibid.

35. Ibid., at p. 2 .

36. Canada, House of Commons Official Report of Debates (Hansard), II (April 5, 1932), at p. 1703. A Department of Justice internal memorandum confirms the influence of the C.B.A. Report on the Bankruptcy Bill. "Memorandum re Bankruptcy Bill" (1932), Department of Justice Papers, R.G. 13, Box 2217, File No. 1932-1934, L.A.C.

37. P.B. Waite, In Search of R.B. Bennett (Montreal and Kingston: McGill-Queen's University Press, 2012) at p. 71. See also the list of Past C.B.A. Presidents, online <https:/www.cba.org/Who-We-Are/Governance/Board-ofDirectors/Past-CBA-Presidents>.

38. The Bankruptcy Act, R.S.C. 1927, c. 11, as amended by An Act to amend the Bankruptcy Act, S.C. 1931, c. 17; An Act to amend the Bankruptcy Act (Priority of Claims), S.C. 1931, c. 18; An Act to amend the Bankruptcy Act, S.C. 1932, c. 39 , s. $36 \mathrm{~A}(1)$.

39. F.P. Varcoe, Memorandum to Minister of Justice, (February 23, 1932), Department of Justice Papers, R.G. 13A2, vol. 2217, File 934/1932, L.A.C.

40. Bankruptcy Act, supra, footnote 38, s. 36A(2).
} 
of investigation and the ability to inspect any bankruptcy estate. ${ }^{41}$ More importantly, the legislation set up a mandatory licencing regime for trustees in bankruptcy. The legislation required applicants to apply directly to the Superintendent who was to investigate "the character, business experience, and efficiency of the applicant." 42 The Superintendent's report on the applicant was crucial. As John Honsberger notes, "[i]f the applicant measured up to the requisite standards, the licence was issued by the Minister on the recommendation of the Superintendent."43 Once the licence was issued, Reilley continued to have broad oversight. Reilley had responsibility for licence renewals ${ }^{44}$ and was required to report to the Minister if it appeared that a licensed trustee had "not fully complied with the law." 45 The Minister, after receiving any report from the Superintendent, could "suspend or cancel any licence" 46 and these powers of suspension or cancellation could be used as threats to govern recalcitrant trustees.

\section{OPPOSITION TO THE SUPERINTENDENT OF BANKRUPTCY}

\section{Political Opposition}

In 1932, there was a broad consensus on the need to license and regulate trustees. Such regulation could be best achieved through a federal civil servant at the apex of the entire bankruptcy regime. The House of Commons Special Committee on Bill C-41 (after six days of testimony and hearing from 19 witnesses) unanimously approved the bankruptcy reforms. When the matter moved to the House of Commons and the Senate, the Bill passed with broad support. By establishing the Superintendent's position, Parliament recognized that the state had an interest in the administration of bankruptcies, ${ }^{47}$ but not all agreed. In the midst of the Great Depression some were reluctant to grow the size of the state and there was a fear of a new bankruptcy bureaucracy. Creating a new government official to supervise trustees was a dramatic departure from a prior policy decision to leave trustee regulation to the market.

In 1919, Parliament had made a deliberate policy choice not to provide government oversight of trustees and many defended the lack of state apparatus. ${ }^{48}$ Thus, in 1920, the Monetary Times reported that the Bankruptcy Act would need "very little administrative machinery at Ottawa." ${ }^{49}$ H.P. Grundy, who had drafted the 1919 Bankruptcy Act, defended the lack of regulatory oversight in a 1927 article published in the Monetary Times. He argued that the Canadian Act avoided the "expensive red tape machinery which exists under the English and American Acts." 50 In the 1920s, there were reform proposals asking for greater government oversight. One such proposal was sensitive to the charge that reforms would create a bankruptcy department. Saturday

41. Ibid., s. $36 \mathrm{~A}(2)$.

42. Ibid., s. 36A(3).

43. John Honsberger, "Bankruptcy Administration in the United States and Canada" (1975), 63 Cal. L. Rev. 1515, at p. 1535 .

44. Bankruptcy Act, supra, footnote 38, s. 36A(3)(c). Licences expired on the $31^{\text {st }}$ of each year and could be renewed from year to year.

45. Ibid., s. 36A(3)(h).

46. Ibid., s. 36A(4).

47. Albert Bohémier, Faillite et Insolvabilité, Tome 1 (Montreal: Éditions Thémis, 1992) at p. 479.

48. Bram Thomson, "Canadian Bankruptcy Act-Monopoly of the Trusteeship and of the Law" (1921), 41 Can. L.T. 96.

49. "Operations of the Dominion Bankruptcy Act," 65:25 The Monetary Times, December 17, 1920, p. 7.

50. H.P. Grundy, "Bankruptcy Act a Real Benefit," 78:24 The Monetary Times, June 17, 1927, p. 14. 
Night's 1925 proposal for a "Government Department" was not to be "formed with its attendant red tape and hosts of indolent office holders." Lest the author be accused of nefariously growing the size of the state, the writer assured readers that the suggestion for regulation did not emanate "from Leningrad." The editorial explained that any new department would not require great numbers of staff. Under Saturday Night's proposal the "new officer would be a guardian and a watch dog, perhaps a bit of a fox hound" but his duties would be "fairly simple and capable of being performed within a short time." 51

An unregulated bankruptcy regime, however, proved to be too costly. Hugh Guthrie, Minister of Justice, noted the cost of administration was a "chief complaint" and that in some instances there had been reports "that the fees paid to trustees, [and] to lawyers...eat up the whole available estate so there is nothing left for the creditors." 52 Senator Meighen echoed this sentiment, noting that "creditors have had very bare bones" by the time that trustees and lawyers had been paid. ${ }^{53}$ Under the new regime, the government claimed that "every cent of the estate" would be "properly accounted for" since the Ministry of Finance would "have a man there in the position of superintendent to see that that scale is not exceeded." 54 The Superintendent would therefore reduce the costs of administering bankruptcies. Guthrie claimed that "it has been considered that if someone had a commanding position in control of the whole machinery, having jurisdiction throughout the whole of Canada, much of the expense now involved in the winding up of estates might be done away with." 55

Not all MPs agreed with the idea of building a new bankruptcy bureaucracy in Ottawa. Franklin Turnbull, a Conservative MP from Regina, broke with Bennett's government to condemn the amendments. He was "sorry to see the growth of any large amount of government departmental assistance to the superintendent, and would be very sorry to see any great extent of financial responsibility incurred." 56 Turnbull feared broad investigatory powers would lead to the "building up of a very large and expensive staff at Ottawa under the superintendent of bankruptcy." ${ }^{\circ 7}$ Turnbull noted that the requirement to keep a "close and constant supervision over the administration of estates" would be difficult and costly. Turnbull claimed that "these estates are scattered all over Canada and are numerous, will mean the necessity of keeping a fairly substantial staff for the purpose of taking care of that supervision and inspection. For it is not merely supervision, it is inspection as well." 58

\footnotetext{
51. Terence Sheard, "Present Canadian Bankruptcy Act Will Not Do," 40:9 Saturday Night, 1925, p. 13.

52. Canada, House of Commons Official Report of Debates (Hansard), II (April 5, 1932), at p. 1703 (Hon. Hugh Guthrie).

53. Canada, Senate, Official Report of Debates (Hansard), I (May 24, 1932), at p. 459 (Right Hon. Arthur Meighen).

54. Canada, House of Commons, Official Report of Debates Canada, (Hansard), vol. III (May 19, 1932), at pp. $3083-84$ (Hon. Hugh Guthrie)

55. Canada, House of Commons Official Report of Debates (Hansard), II (April 5, 1932), at p. $1703-04$ (Hon. Hugh Guthrie).

56. Canada, House of Commons, Official Report of Debates (Hansard), III (May 19, 1932), at p. 3069 (Franklin White Turnbull). Business leaders reported to Robert Thayer that they did not believe the solution to the trustee problem was more supervision. They were satisfied with the creditor control model established by the 1919 Act. See Thayer Report at p. 265.

57. Ibid., at p. 3071 (Franklin White Turnbull).

58. Ibid., at pp. 3069-70 (Franklin White Turnbull).
} 
Arthur Cardin, a Liberal MP from Québec, argued that overall bankruptcy costs would not be reduced given that the Superintendent "and his staff will have to be paid." 59 According to Cardin, the Superintendent's investigations would take him across "the whole of Canada," supported by an "assistant... accountants, stenographers and other officials." 60 Cardin was of the view that the present Bill would create "a new bureaucracy, and from now on the affairs of insolvent debtors are going to be governed, not by law, but by regulations." ${ }^{61}$ There was also a fear that the government may be liable in the event there was a loss to creditors where it was discovered that "supervising by the superintendent had not been efficient." 62

Before the Parliamentary Special Committee on Bill C-41, G.T. Clarkson, representing the Toronto Board of Trade, expressed deep concern about the wide investigatory powers of the Superintendent. The Superintendent could launch an inspection of a bankrupt estate without having to wait for a formal complaint. Some feared that such broad powers would have to be supported by a large staff. Clarkson claimed that under the Bill the Superintendent "will have an enormous department. [The Toronto Board of Trade is] very much set against such wide powers being given to him, also set against the cost being set as a burden on the estate." 63 In a separate letter to the Ministry of Justice, the Toronto Board of Trade "feared" that a "large separate department will in due course grow up involving heavy expenses which will be doubtless charged against the bankrupt estate." 64 A 1933 American law journal recognized the implications of the Superintendent's broad powers. Reilley had "virtually carte blanche to delve into the countless" individual bankruptcies. If Reilley's powers were carried out "literally," it might mean "the setting up of [a virtual] national detective agency...on all phases of bankruptcy in Canada." 65

To respond to concerns that Parliament was creating a new expensive bureaucracy, the government imposed a levy "on all payments made by the trustee," including payments of dividends by the trustee to creditors. ${ }^{66}$ The purpose was to defray the expenses of the Superintendent ${ }^{67}$ and the levy was to be paid to the Receiver General. ${ }^{68}$ An internal Department of Justice document optimistically claimed that the "estimated revenue would pay for the supervision" of the

59. Ibid., at p. 3062 (Pierre-Joseph-Arthur Cardin).

60. Ibid., at p. 3071 (Pierre-Joseph-Arthur Cardin).

61. Ibid., at p. 3062 (Pierre-Joseph-Arthur Cardin).

62. Ibid., at p. 3071 (Pierre-Joseph-Arthur Cardin).

63. Canada, House of Commons, Special Committee on Bill No. 41, An Act to Amend the Bankruptcy Act, Minutes of Proceedings and Evidence No. 1 (April 1932), at pp. 13 - 14 (Clarkson).

64. Toronto Board of Trade to Minister of Justice, (April 16, 1932), Bennett Papers, MG26K. Reel M966, p. 66516, L.A.C.

65. "Canada's Bankruptcy Superintendent", supra, footnote 1.

66. Bankruptcy Act, supra, footnote 38, s. 126(A). On the scope of the levy see Lavallée c. Lamarre (1933), 15 C.B.R. 159 (Que. C.S.); Allan's Ltd. v. Lamarre (1932), 14 C.B.R. 179 (Que. C.S.); Colonial Manufacturing Co., Re, [1934] 1 D.L.R. 703 (Ont. Sup. Ct.); Labbe v. Bonnier (1938), 19 C.B.R. 243 (Que. C.S.), at para. 9. The levy continues to exist today. See Bankruptcy and Insolvency Act, R.S.C. 1985, c. B-3, s. 147.

67. Bankruptcy Act, supra, footnote 38, s. 126(A). The Manitoba Court of Appeal in recent decision concluded that the levy was to ensure that all creditors that received a bankruptcy distribution "contribute to the cost of supervision of those proceedings." Superintendent of Bankruptcy v. Business Development Bank of Canada, (2019), 71 C.B.R. (6th) 30 (Man. C.A), at para. 6.

68. Bankruptcy Act, supra, footnote 38, s. 126(A). The levy did not impact fees and expenses of the trustee. P.C. 2588, November 23, 1932 fixed the levy at one-half of one percent. See Lewis Duncan and William John Reilley, Bankruptcy in Canada, 2nd ed. (Toronto: Canadian Legal Authors, 1933) at p. 725. 
Superintendent. ${ }^{69}$ Although the levy helped fund the office of the Superintendent, there was still resistance to this model. Two witnesses who appeared before the Parliamentary Special Committee opposed the levy. H.P. Grundy, representing the Canadian Credit Men's Trust Association, claimed that "[i]f this committee and this parliament deems it advisable for the purpose of putting the administration of bankruptcy on a clean and proper basis that there should be a superintendent, then we are not opposing it provided we [the creditors] do not have to pay the shot." ${ }^{70}$ G.T. Clarkson, representing the Toronto Board of Trade, stated that "[i]t is all right to approve of superintendents and the licensing of trustees providing the cost is paid by the Government." "Lewis Duncan warned that the levy "is unnecessarily irritating and will no doubt be used for propagandist purposes by interests opposed to the continuation of the office of Superintendent."72 Opponents ${ }^{73}$ of the Superintendent and levy did not succeed in preventing the new bankruptcy bureaucracy from being established. There was broad consensus in Parliament that reform was required. The creation of a new state apparatus during the Great Depression did raise real and significant issues for some MPs and interest groups. But such opposition could not overcome Bennett's willingness to rely upon state regulation.

It was Bennett, a self-proclaimed reformer, who presided over the creation of the new administrative agency of the Superintendent of Bankruptcy. During his time in office Bennett did not shy away from using the power of the state. This was the government that created the CBC, the Bank of Canada, and the Canadian Wheat Board, and had passed the National Products Marketing Act. ${ }^{74}$ Bennett would later say in 1934, "I am for reform. And, in my mind, reform means Government intervention. It means Government control and regulation."75 In a 1935 radio address, in which Bennett revealed his New Deal proposals, he said: ${ }^{76}$

And, in my mind, reform means Government intervention. It means Government control and regulation. It means the end of laissez faire. Reform heralds certain recovery. There can be no permanent recovery without reform. Reform or no reform! I raise that issue squarely. I nail the flag to the masthead. I summon the power of the State to its support.

Bennett's use of the state and his New Deal proposals (e.g. the regulation of hours and wages, and unemployment insurance) $)^{77}$ are well known but the creation of the new regulatory office of the Superintendent of Bankruptcy has been overlooked by historians of the Great Depression.

\footnotetext{
69. Memorandum for Deputy Minister of Justice, (February 4, 1932), Department of Justice Papers, R.G. 13-A, Box 2217, File No. 1932-1934, L.A.C, at p. 2.

70. Special Committee on Bill No. 41, supra, footnote 63, at p. 3 (Chair: John T Hackett). It is clear that the government privately consulted with H.P. Grundy, the drafter of the original Bankruptcy Act. F.P. Varcoe, Department of Justice to H.P. Grundy, (January 23, 1932), Department of Justice Papers, R.G. 13-A, Box 2217, File No 1932-1934, L.A.C.

71. Special Committee on Bill No. 41, supra, footnote 63, at p. 14 (Chair: John T Hackett).

72. Duncan, supra, footnote 3, at p. 101.

73. See e.g. Saint John Board of Trade to Minister of Justice, (February 15, 1932), Department of Justice Papers, R.G. 13-A, Box 2217, File No. 1932-1934, L.A.C.

74. Thompson and Seager, supra, footnote 18, at pp. 256-257; Alvin Finkel, Business and Social Reform in the Thirties (Toronto: James Lorimer, 1979) at p. 58. The Natural Products Marketing Act, S.C. 1934, c. 64 was later declared to be ultra vires. Reference re Natural Products Marketing Act, 1934, [1937] 1 D.L.R. 691 (P.C.).

75. Ottawa Citizen, December 15, 1934 as cited in P.B. Waite, In Search of R.B. Bennett (Montreal and Kingston: McGill-Queen's University Press, 2012) at p. 199.

76. J.R.H. Wilbur, The Bennett New Deal: Fraud or Portent (Toronto: Copp Clark Publishing Company, 1968) at p. 81.

77. Many of Bennett's New Deal promises would ultimately be overturned by the Privy Council on the basis that the federal government did not have jurisdiction over these issues. See e.g., Reference re The Weekly Rest in Industrial
} 
There was little opposition to the reforms from the Canadian legal profession. In contrast to the Canadian experience, David Skeel's study of U.S. bankruptcy reform reveals that the bankruptcy bar "derailed" proposals to provide government oversight of the bankruptcy regime. ${ }^{78}$ A 1932 Congressional Bill proposed to appoint a staff of government administrators to supervise the bankruptcy system. ${ }^{79}$ As Skeel notes, the theme of the proposed changes was clear: "lawmakers should shift a large dose of control from the parties and their lawyers to governmental administrators." 80 When Congress introduced reforms the legal community coalesced to oppose the regime. The National Association of Federal Practitioners, representing the bankruptcy bar, ${ }^{81}$ claimed that if the Bill were to pass, bankruptcy estates would come under "bureaucratic domination, and cost the taxpayers millions of dollars," leaving lawyers without any role in bankruptcy cases. ${ }^{82}$ Congress never adopted these sweeping reforms. Skeel notes that the only effective organized group opposing bankruptcy reform was the bankruptcy bar. Skeel suggests that "lawyers were the principal obstacle to more sweeping, structural change." 83 In the United States, the bankruptcy bar played a dominant role in bankruptcy files, and opposed any changes that would threaten that role.

In Canada, lawyers have only ever played a minor role in personal bankruptcy proceedings. ${ }^{84}$ The Thayer Report notes that in the Western provinces lawyers were not required in bankruptcy matters. In the East, the report concluded that when lawyers were involved fees were limited. ${ }^{85}$ When Thayer sought input from lawyers they claimed that "liquidation [arising from a bankruptcy] is an economic [order] rather than a legal function." The Bankruptcy Act "resulted in a lack of need for their services and a resultant diminution in the volume of their practice[s]." 86 When H.P. Grundy, the drafter of the Canadian Bankruptcy Act, testified before the Donovan Committee he described the Canadian regime as cheaper than US bankruptcy proceedings. Grundy noted that the Canadian Act "practically eliminates lawyers from all bankruptcy proceedings and abolishes

\footnotetext{
Undertakings Act, Minimum Wages Act and The Limitation of Hours of Work Act, [1937] 1 D.L.R. 673 (P.C.); Reference re The Employment and Social Insurance Act, 1935, [1937] 1 D.L.R. 684 (P.C.). See E.A. Heaman, A Short History of the State in Canada (Toronto: University of Toronto Press, 2015) at p. 170; W. H. McConnell, "The Judicial Review of Prime Minister Bennett's New Deal" (1968), 6 Osgoode Hall L.J. 39, at p. 41. However, the F.C.A.A. was upheld by the Privy Council in British Columbia (Attorney General) v. Canada (Attorney General), [1936] S.C.R. 384, 3 D.L.R. 610 (S.C.C.) [F.C.A.A. Reference]; British Columbia (Attorney General) v. Canada (Attorney General), [1937] 1 W.W.R. 320, 1 D.L.R. 695 (J.C.P.C.).

78. David A. Skeel, Debt's Dominion: A History of Bankruptcy Law in America (Princeton: Princeton University Press, 2001) at p. 79.

79. Ibid., at p. 74 .

80. Ibid., at p. 79.

81. Ibid., at p. 91. Skeel notes that this group of bankruptcy lawyers was formed to oppose the Bill. See also M. Susan Murane, Bankruptcy in an Industrial Society (Akron: University of Akron Press, 2015) at p. 133.

82. Jacob Weinstein, Letter on Behalf of the National Association of Federal Practitioners, 1932 cited in Skeel, supra, footnote 78 , at p. 91 .

83. Skeel, supra, footnote 78 , at p. 92.

84. Some of the best literature on the operation of the Bankruptcy Act can be found in the Canadian Chartered Accountant journal. See e.g. G.T. Clarkson, "The Bankruptcy Act" (1920-21), 10 Can. Chartered Accountant 154; Osler Wade, "The Dominion Bankruptcy Act" (1921), 10 Can. Chartered Accountant 234.

85. Thayer, supra, footnote 22, at p. 258.

86. Ibid., at p. 265.
} 
red tape." ${ }^{87} \mathrm{He}$ claimed that the Canadian system was more efficient as it eliminated "any abuse on the part of attorneys in making use of the bankruptcy machinery for the purpose of getting fees." 88

Although lawyers had a limited role in Canadian bankruptcy proceedings, it was the CBA's influential report that ultimately led to the 1932 administrative reforms. Unlike the United States, the Canadian legal community did not oppose reforms. The Canadian legal profession had no substantial bankruptcy practice to protect. Even Canadian trustees did not launch any opposition to the proposed new administrative regime, likely because they did not view it as a threat to their livelihood. Those trustees who had practised prior to 1932 were counting on becoming a licensed trustee. The licensing regime would help curtail competition as it limited the number of incoming trustees. Opposition to the new licensing regime did not raise its head until after Reilley announced the results of the first licensing applications. Reilley's announcement of who was to be a licensed trustee in Québec resulted in his censure by the Montreal Bar. To understand the controversy of Reilley in Québec, it is important to provide some constitutional law context from the 1920s to identify why there might be Québec opposition.

\section{Opposition to the Superintendent: The Constitutional Perspective}

The threat of a new federal administrative bankruptcy department raised questions about the limits of the federal bankruptcy power under the British North America Act, 1867, but there were no constitutional challenges to the new Superintendent's powers. This contrasted with the constitutional uncertainty surrounding the federal bankruptcy power in the 1920s. ${ }^{89}$ Throughout the 1920s, many in Quebec opposed the federal bankruptcy law's interference with the Civil Code. The Privy Council in Royal Bank of Canada v. Larue ${ }^{90}$ ended that uncertainty by ruling that the federal Bankruptcy Act took precedence over Québec judicial hypothecs reducing judgments to a state of equality in a bankruptcy. When the Privy Council released its decision in 1928, the Revue du Droit published "Démolisseurs!," in which a Québec lawyer condemned Royal Bank v. Larue as destructive to Québec civil law: ${ }^{91}$

This disastrous, literally inexplicable decision made one more, broader blow in the barrier of protection that surrounded our provincial law. It was already quite damaged. It falls, of course, into ruins and no longer offers any security: how could one place its trust in it?

Given the political and constitutional context of the 1920s, it is not surprising that provincial rights arguments surfaced when Parliament sought to create a new federal official in Ottawa. But in 1932 it was only a lone Québec MP who challenged the new Superintendent's office from a provincial rights perspective. Arthur Cardin conceded that Parliament had the power to generalize the application of bankruptcy to all of Canada; however, he claimed that the people in the province

87. “Donovan Inquiry Weighs Canadian Law,” The New York Times, September 5, 1929, p. 26.

88. Ibid.

89. See Thomas G.W. Telfer, "Rediscovering the Bankruptcy and Insolvency Power: Political and Constitutional Challenges to the Canadian Bankruptcy Act, 1919-1929” (2017), 80 Sask. L. Rev. 37.

90. Royal Bank of Canada v. Larue, [1928] A.C. 187 (P.C.).

91. Alexandre Gérin-Lajoie, "Démolisseurs! Pour ne pas dire pire" (1928), 6 R. du D. 449 at p. 464 [translated by author]. Démolisseurs translates into demolishers or wreckers. 
of Québec had been "suffering severely from the application" of the Bankruptcy Act. ${ }^{92}$ Cardin feared that the "new bureaucracy" would govern "not by law, but by regulations" and from Québec's perspective would "impair the application of our civil laws." Cardin feared that the "new organization at Ottawa... will be in a position to dictate to all the provinces." ${ }^{94}$ Cardin argued that Parliament should "repeal the Bankruptcy Act" and return the regulation of debtor-creditor matters to the provinces. Unlike the extensive 1923 Parliamentary debates in which several Québec MPs argued in favour of repeal of the Bankruptcy Act, in 1932 no other Québec MP stood to support or endorse Cardin's demand to abrogate the federal law.

Given the thrust of the constitutional case law in the years immediately prior to and following the 1932 amendments, it would have been difficult, if not impossible, to make a successful argument that the Superintendent's powers or the licencing of trustees was not a proper exercise of the federal bankruptcy and insolvency power. Larue and several decisions throughout the 1930s continued to uphold the broad ambit of the federal bankruptcy and insolvency power under the Constitution in cases involving the Bankruptcy Act. ${ }^{95}$ In addition, the federal acts that dealt with insolvent companies ${ }^{96}$ and insolvent farmers ${ }^{97}$ were held to be valid exercises of the bankruptcy and insolvency power. ${ }^{98}$ Since a constitutional challenge to the federal Bankruptcy Act was unlikely to succeed, the Montreal Bar sought other ways to confront the first Superintendent of Bankruptcy.

\section{William John Reilley and The Montreal Bar's Resolution of Censure}

\footnotetext{
92. Canada, House of Commons, Official Report of Debates (Hansard), III (19 May 1932), at p. 3062 (Pierre-JosephArthur Cardin).

93. Ibid.

94. Ibid.

95. Hoffar Ltd. v. Canadian Credit Men's Trust Association, [1929] 2 D.L.R. 73; Pommier, Re, [1930] 4 D.L.R. 113 (Ont. S.C.); Stuart v. Sutterby, [1931] 1 D.L.R. 754 (Ont. S.C.); Beiswanger (Plaintiff) Appellant v. City of Swift Current (Defendant) Respondent, [1931] 1 D.L.R. 407, at pp. 409-10; In re Society Shirt Company Limited, [1932] 1 D.L.R. 561, 13 C.B.R. 216, at p. 561; Re Solloway, Mills \& Co. Ltd., [1935] 1 D.L.R. 340 (Ont. C.A.), at p. 344; In re R.W. Minielly, [1936] 2 D.L.R. 281 (Ont. C.A.), at p. 283; Gard v. Yates, [1936] 2 D.L.R. 50 (B.C.S.C.), at pp. 56-57; Ladore et al. (Plaintiffs) Appellants v. Bennett et al. (Defendants) Respondents, [1939] 3 D.L.R. 1 (P.C.), at pp. 6-7.

96. Companies' Creditors Arrangement Act, supra, footnote 15.

97. Farmers' Creditors Arrangement Act, supra, footnote 16.

98. Reference re Companies' Creditors Arrangement Act (Canada), [1934] 4 D.L.R. 75 (S.C.C.); British Columbia (Attorney General) v. Canada (Attorney General), [1937] 1 D.L.R. 695 (P.C.).
} 


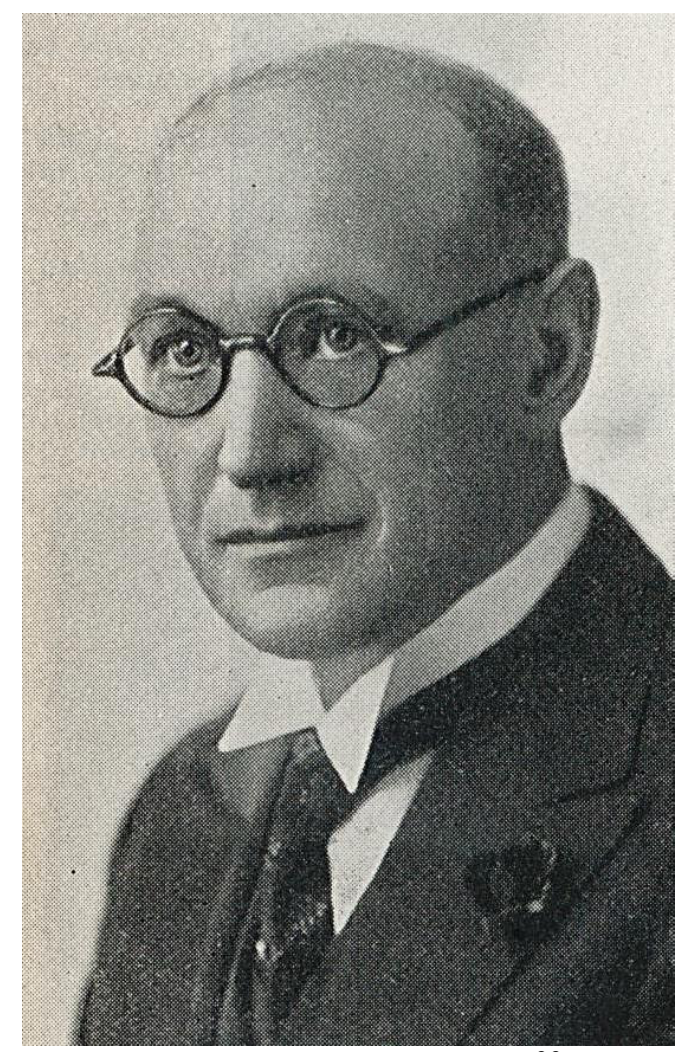

William J. Reilley, $1935^{99}$

The appointment of William J. Reilley was not accepted by all. In 1934, the Montreal Bar passed a motion of censure attacking his qualifications. His background demonstrates that he had the relevant experience for the position. Reilley trained as a lawyer in Alberta and practised in Ontario. In June 1924, Reilley became assistant Master of Ontario's Supreme Court ${ }^{100}$ and four years later he was appointed as the Registrar of the Bankruptcy Court of Ontario. During the eight years that Reilley spent at Osgoode Hall, “...nearly 6,000 bankruptcies [...] passed through his hands involving total liabilities of over $\$ 125,000,000 . " 101$ As Registrar, Reilley performed a judicial role and many of his decisions are reported in the Canadian Bankruptcy Reports.

William J. Reilley's ultimate appointment as Superintendent was well received by the Toronto media. ${ }^{102}$ The Globe prominently featured his appointment story on its front page. ${ }^{103}$ Lewis Duncan, a leading Ontario bankruptcy lawyer and author, ${ }^{104}$ praised the appointment: "An excellent beginning has been made, in the appointment as Superintendent of Bankruptcy, of Mr. W. J. Reilley, who for eight years has with independence and efficiency discharged the duties of Registrar in Bankruptcy for Ontario." 105 Yet in 1932, a Council of the Montreal Bar demanded Reilley's

\footnotetext{
99. B.M. Greene, ed., Who's Who in Canada 1934-35 (Toronto: The Musson Book Company, 1935) at p. 216.

100. “Obituary” (1946), 16 Fortnightly L.J. 106, at p. 106.

101. Wilson, supra, footnote 4.

102. Ibid.

103. "W.J. Reilley Named as Superintendent of Bankruptcy” The Globe, September 15, 1932, at p. 1.

104. Lewis Duncan, The Law and Practice of Bankruptcy in Canada (Toronto: Carswell, 1922); Lewis Duncan and William John Reilley, Bankruptcy in Canada, 2nd ed. (Toronto: Canadian Legal Authors, 1933).

105. Duncan, supra, footnote 3, at p. 103.
} 
resignation. ${ }^{106}$ In modern accounts of the origins of the Superintendent's office there is no mention of the Montreal Bar's reaction. ${ }^{107}$

On December 16, 1932, the new Superintendent of Bankruptcy spoke to a large gathering of nearly 200 "trustees, former trustees and lawyers" in a Montreal courthouse. ${ }^{108}$ Reilley's address "was really a definition of his position, a statement of the action he will take toward his job of seeing that the trustees do theirs." 109 Those who reported on Reilley's speech did not provide extensive analysis or suggest that Reilley had said anything controversial. His remarks, however, caused "indignation" 110 and the Bar of Montreal passed a Resolution of censure against Reilley. According to the Resolution, Reilley "stated, and allowed to be stated...thoughtless and injurious remarks against the Bankruptcy Court and the Bar of Montreal." 111 Consistent with earlier provincial rights attacks on the Bankruptcy Act, the Montreal Bar claimed that "without right or reason" Reilley had "obtruded himself into the administration of the Bankruptcy law" in Montreal. According to the Montreal Bar, Reilley was dealing with subjects which were "exclusively" within the jurisdiction of the provincial bankruptcy judge and of the Chief Justice. ${ }^{112}$ But constitutional law did not provide a realistic way to challenge the authority of the Superintendent.

Turning away from jurisdictional issues, the Montreal Bar attacked Reilley's personal qualifications. The Montreal Bar sought a Superintendent that was fluent in both French and English. ${ }^{113}$ While the Bar recognized Reilley's knowledge of the Bankruptcy Act, they nonetheless believed that he lacked the qualifications "required of an official in the position that he occupies." His qualifications fell short because of "his ignorance of the French language and of the laws of the Province of Quebec." In addition, "his lack of tact, his absence of judgment and of discernment raise[d] doubts as to his competence to fulfill the high position that has been conferred upon him." 114 The Montreal Bar resolution further stated " $[\mathrm{t}]$ hat the attitude and conduct of Mr. Reilley constitute an insult to the French-Canadian population of this city and show[s] contempt towards the Bench and Bar of this district." 115

The final grievance raised by the Montreal Bar was the licencing of trustees in Montreal. The Department of Justice recognized that there were over 100 trustees operating in Montreal under the old regime with the generally held view that no more than 20 licenced trustees should be carrying on business in the city. ${ }^{116}$ It was inevitable that when Reilley announced the licences for Montreal trustees there was bound to be a critical reaction. Although trustee licences were to be granted under the authority of the Minister of Finance, Reilley had responsibility for administering the licensing

\footnotetext{
106. “Surintendant des faillites" (1934-35), 13 R. du D 314.

107. Honsberger, supra, footnote 43. Bohémier, supra, footnote 47.

108. "New Bankruptcy Official Outlines New Provisions in Address at Montreal" (1933), 3 B. Bar Nat'1 Legal Newspaper

1.

109. Ibid.

110. "Bankruptcy Head Under Fire” (1933), 2 Fortnightly L.J. 201, at p. 212.

111. "Montreal Lawyers Sternly Critical of New Official," The Globe, December 21, 1932, p. 2.

112. "Bankruptcy Head Under Fire", supra, footnote 111.

113. "Résolution de censure" (1933), 11 R. du D. 317, at p. 318.

114. "Bankruptcy Head Under Fire", supra, footnote 111.

115. Ibid.

116. Memorandum for the Deputy Minister of Justice Re: Bill to Amend the Bankruptcy Act, (February 4, 1932), Department of Justice Papers, R.G. 13-A, Box 2217, File No. 1932-1934, L.A.C.
} 
regime. ${ }^{117}$ Reilley's recommendations to the Minister of Finance in practice determined which applicants would receive licences. ${ }^{118}$ The Montreal Bar asserted that the principle underlying the new Act was that licences were to be "granted to the existing trustees unless there be some grave reasons against them." 119 The Montreal Bar's resolution strongly suggested that existing trustees had not fared well under Reilley's licencing regime. Disappointed with the allocation of trustee licences in Québec, the Bar's complaint was infused with anti-Semitism: ${ }^{120}$

the council is informed that in the choice of trustees in Montreal, Mr. Reilley has obviously been unduly influenced in recommending the granting of about fifteen licences to French-Canadians, against forty to English trustees, and ten to Jewish trustees.

In a front page story Le Devoir reported on the licence allocation concluding that "en effect les Juifs ont gagné du terrain toute la semaine et sont passés de 7 à $10 .{ }^{.121}$

Anti-Semitism also arose in other complaints about the bankruptcy regime. In 1933, the Confederation of Catholic Workers of Canada issued a memo calling for bankruptcy reform and stated: "We beg the Federal Government not to allow mass immigration of German-Jews to Canada, particularly to the province of Quebec." ${ }^{22}$ From Saskatchewan, Harold B. Long wrote to the Attorney General of Canada complaining of a condition that "prevails here and I dare say over all of the Dominion": 123

It is the fact that Jews can go broke with a full pocket, buy back the bankrupt stock, start up again and make it harder than ever for the honest business man who is here year in and out. These chaps drift into a village rent an old building, sell under cost whilst we are powerless to do a thing but look on and take it... Anything you can do to alleviate this disastrous condition will be greatly appreciated.

The controversy of Reilley's appointment did not disappear overnight. By 1933, a Québec MP sought to introduce a Bill which would have created a "joint superintendent of bankruptcy" who would be familiar with both official languages and Québec Civil Law. ${ }^{124}$ The Bill was not

117. Bankruptcy Act, supra, footnote 38, s. 36(3). In 1933, Senator Arthur Meighen lobbied Reilley to appoint T.J. Lytle of Winnipeg as trustee. See Arthur Meighen to W.J. Reilley, March 8, 1932, Arthur Meighen Papers, M.G. 26 I, vol. 181, Reel C-3570, p. 114391, L.A.C.

118. Honsberger, supra, footnote 43, at p. 1535.

119. "Bankruptcy Head Under Fire" supra, footnote 111.

120. Ibid.

121. "Un truc pour monopoliser l'administration des faillites," Le Devoir, December 18, 1932, p. 1. The complaints about appointing Jewish trustees should be seen in light of anti-Semitism in Quebec in the 1930s. See e.g. Gerald J.J. Tulchinsky, Canada's Jews: A People's Journey (Toronto: University of Toronto Press, 2008) at pp. 233-237, 301-327; Jacques Langlais and David Rome, Jews and Quebecers: Two Hundred Years of Shared History (Waterloo: Wilfrid Laurier Press, 1991) at pp. 84-99. For a discussion of anti-Semitism in the context of US bankruptcy reform see Linda Coco, "Stigma Prestige and the Cultural Context of Debt: A Critical Analysis of the Bankruptcy Judge's Non-Article III Status" (2011), 16 Mich. J. Race \& L. 183, at p. 211.

122. "Bankruptcy Act Law: Requests of the Confederation of the Catholic Workers of Canada" (1933), Bennett Papers, M.G. 26-K, Reel M-966, p. 66643, L.A.C.

${ }^{123 .}$ Harold B. Long, Naicam Saskatchewan to Attorney General of Canada, (January 16, 1930), Department of Justice Papers, R.G. 13, vol. 350, File 1931-234, L.A.C.

124. Canada, House of Commons, Official Report of Debates (Hansard) III (March 17, 1933), at p. 3099. L.E. Panneton lobbied for his son to become the Superintendent for Quebec. L.E. Panneton to Secretary of State, May 3, 1933, Bennett Papers, M.G. 26-K, Reel M-966, p. 66607, L.A.C. 
accepted, and later that year a delegation from the Council of the Montreal Bar travelled to Ottawa to meet with the Minister of Finance to seek the resignation of the Superintendent of Bankruptcy. ${ }^{125}$

Reilley did not resign. Although the Montreal Bar's resolution had attracted national attention, Reilley fared the storm and emerged seemingly unscathed. ${ }^{126}$ In 1933 , he was appointed King's Counsel. In that same year, he published, as a co-author, what was to become the leading Canadian bankruptcy text. ${ }^{127}$ The book was widely cited by courts throughout the 1930 s. ${ }^{128}$ A Professor of Civil Law at the Université de Montréal praised the book in Revue du Droit and recommended it for the library of "any French-Canadian lawyer." 129 Reilley's reputation extended to south of the border. As Superintendent, he became well known in bankruptcy circles in the US given that he attended a number of American bankruptcy conferences. ${ }^{130}$ Reilley began the tradition of Annual Reports containing statistics - a function that the Office of the Superintendent carries out to this day. ${ }^{131}$ Reilley remained at the helm of the new "national detective agency" until he died. On October 9, 1946, Reilley died suddenly at his residence following a "seizure...at work."132 Canada's first Superintendent of Bankruptcy was $64 .{ }^{133}$ Reilley served for fourteen years and to this day Reilley remains the longest serving Superintendent of Bankruptcy. ${ }^{134}$

\section{CONCLUSION}

The Superintendent of Bankruptcy continues to perform an important function in the bankruptcy system and it is widely accepted that the creation of this office in 1932 improved transparency and accountability in the bankruptcy system. Modern explanations of the origins of the Superintendent do not include any reference to opposition to the creation of a new government official in Ottawa. Critics raised the image of a salaried bureaucrat travelling the country with a team of accountants and stenographers. Many warned against the creation of a new bankruptcy

125. "Surintendant des faillites", supra, footnote 107.

126. Even as late as December 1934 the controversy over Reilley's appointment had not subsided. In a letter to the Secretary to Bennett, H.R. Drummond-Hay stated, "I hear that the members of the Montreal Bar Association are after Reilley's scalp." Drummond-Hay suggested his law partner, H.P. Grundy the drafter of the Bankruptcy Act, as the new Superintendent. Drummond-Hay to Secretary to the Prime Minister, December 6, 1934, R.B. Bennett Papers, M.G. 26K, Reel M-966, p. 66714, L.A.C.

127. Lewis Duncan and William John Reilley, Bankruptcy in Canada, 2nd ed. (Toronto: Canadian Legal Authors, 1933).

128. See e.g. Re Belleville Milling Co. Ltd., [1930] O.J. No. 335, at para. 12; Trenwith v. Trenwith (Trustee of), [1933] O.J. No. 339, at para. 9; Lake Shore Golf \& Country Club Ltd. (Re), [1933] O.J. No. 223, at para. 3; W.N. McEachren \& Sons, Ltd. (Trustee of) (Re), [1933] O.J. No. 345, at para. 12; Grobstein c. New York Life Insurance Co. (1935), 17 C.B.R. 315 (Que. K.B.), at para. 62; In re The Farmers' Creditors Arrangement Act, 1934 Poirier v. North American Life Assurance Company et al., [1936] S.J. No. 12 (Sask. Q.B.), at para. 5; North of Scotland Canadian Mortgage Co. v. Bak (1937), 18 C.B.R. 310 (Sask. Q.B.), at para. 17; H.O. Kirkham (Trustee of) (Re), [1938] B.C.J. No. 44 (B.C.S.C.), at para. 4; Pehlke (Re), [1939] O.J. No. 339, at para. 15. The book is now in its fifth edition: John D. Honsberger and Vern W. DaRe, Honsberger's Bankruptcy in Canada, 5th ed. (Aurora, Ontario: Canada Law Book, 2017).

129. L.E. Beaulieu, "Un livre qui s'impose" (1933), 12 R. du D. 232, at p. 234 [translated by author].

130. "In Attendance" (1947), 21 Nat'l Ass'n Ref. Bankr. 64, at p. 68.

131. See e.g. Superintendent of Bankruptcy, Annual Report for the Period 1 December 1932 to 31 December 1933 (Ottawa, June 22, 1934).

132. “W.J. Reilley Dies Suddenly," Ottawa Journal, October 9, 1946, p. 12. Reilley lived at 295 Clemow Avenue in Ottawa.

133. “Obituary: W.J. Reilley, K.C. of Ottawa” (1946), 16 Fortnightly L.J. 106.

134. Reilley was Canada's first and longest serving Superintendent of Bankruptcy. He held the position from his appointment on September 14th, 1932 until his death on October 9th, 1946. See Canada, Office of the Superintendent of Bankruptcy, “O.S.B. Newsletter 2004-06,” (Ottawa: O.S.B., 2006). 
bureaucracy, as there was reluctance to add to the size of the state. The Montreal Bar's resolution of censure has not been accounted for in the modern literature. The resolution expressed concern that Reilley did not understand French or Québec Civil Law. In part, the Montreal Bar's resolution of censure reflected the reality that any constitutional challenge to his powers would be unsuccessful and that an attack on Reilley's qualifications formed an alternative strategy. To obtain a better understanding of the origins of the Superintendent of Bankruptcy one must move beyond what the reforms achieved and consider the arguments of those who opposed the legislative change.

Finally, one must remember that the debate in 1932 was largely over administrative reforms that had very little to do with the Great Depression. The Bankruptcy Act in 1932 remained a tool for creditors. Debt relief and broadening the bankruptcy legislation was not on Parliament's radar. Superintendent of Bankruptcy William Reilley privately lamented this in a 1933 memo to E.N. Rhodes, the Minister of Finance, claiming that the Bankruptcy Act was "not satisfactory." Pointing to restrictions on creditors found in provincial debt adjustment legislation and the newly enacted Companies' Creditors Arrangement Act, Reilley urged the Minister of Finance to reform the Bankruptcy Act to recognize the "desirability of saving debtors from financial wreckage rather than acting as a wrecking crew." ${ }^{135}$ Perhaps William John Reilley recognized that there was a personal cost to bankruptcy.

${ }^{135 .}$ W.J. Reilley, Memorandum Re Amendments to the Bankruptcy Act to E.N. Rhodes, Minister of Finance, (December 19, 1933), Department of Justice Papers, R.G. 13, vol. 2228, File 790, 1934, L.A.C. 